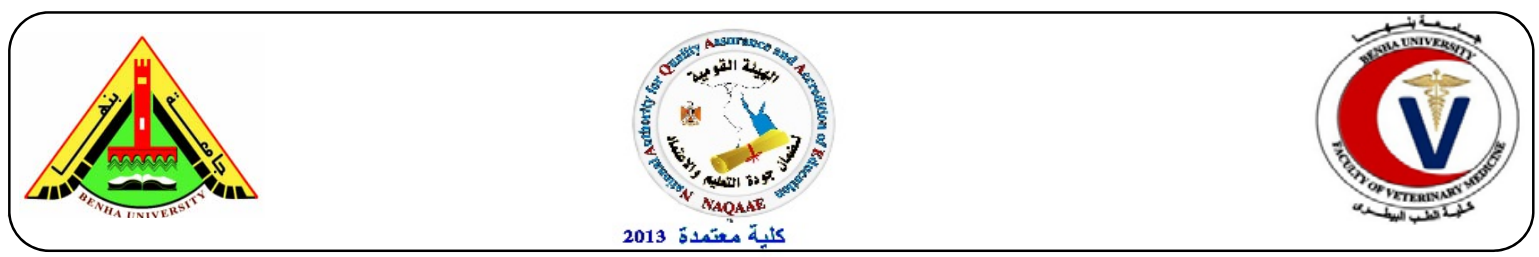

\title{
Prevalence of $E$. coli in broiler chickens in winter and summer seasons by application of PCR with its antibiogram pattern.
}

\author{
Ashraf, A. Abd El Tawab ${ }^{1}$, Samir, A. Abd El Aal ${ }^{2}$, Ebtisam, M. mazied $^{3}$ and Doaa, A. EL. Morsy ${ }^{4}$ \\ ${ }^{1}$ Bacteriology, Immunology and Mycology Dep., Fac. Vet. Med. Benha Univ. ${ }^{2}$ Animal, poultry and \\ environmental hygiene Dep. Fac. Vet. Med. Benha Univ. ${ }^{3}$ Animal Health Research Institute" Dokki". \\ ${ }^{4}$ Animal health research institute "Shebin El. koom Branch"
}

\section{A B S T R A C T}

A total of 205 chicken samples from apparently healthy broiler chickens ( 35 and 30), diseased broiler chickens (35 and 30) and freshly dead ones (35 and 40) were collected in winter (from December to February) and summer (from June to August) seasons, respectively from Menofya government. The results showed that the incidence of $E$. coli in apparently healthy broiler chickens was $15.7 \%$, diseased broiler chickens $37.1 \%$ and in freshly dead ones $55 \%$ in winter season while in summer season was $15.8 \%$ in apparently healthy, $17.5 \%$ in diseased broiler chickens and $18.7 \%$ in freshly dead one. The serogroups of $E$. coli that obtained by serological identification were $\mathrm{O}_{128}, \mathrm{O}_{78}, \mathrm{O}_{111}, \mathrm{O}_{124}, \mathrm{O}_{55}, \mathrm{O}_{142}$, $\mathrm{O}_{114}, \mathrm{O}_{2}$ and $\mathrm{O}_{1}$. The results of antibiotic sensitivity test for isolated $E$. coli showed that the isolated $E$. coli were highly sensitive for norfloxacin $(60 \%)$, gentamycin $(50 \%)$, neomycin $(50 \%)$, streptomycin(50\%) and chloramphenicol (50\%). moderately sensitive for doxcyclin $(10 \%)$ and erythromycin (40\%) and highly resistant for amoxacillin /clavulinic acid (0\%). The results of multiplex PCR showed that eae A (intimin or E. coli attaching and effacing) gene detected in $\mathrm{O}_{128}, \mathrm{O}_{55}, \mathrm{O}_{1}$ and $\mathrm{O}_{2}$ , OmpA(outer membrane protein ) gene detected in all E.coli serogroups that isolated, $s t x_{1}$ gene not detected in all E. coli sergroups that isolated ,but stx 2 gene detected in $\mathrm{O}_{114}$ and $\mathrm{O}_{128}$.

Keywords: E. coli, broiler chickens, PCR, antibiogram pattern

(http://www.bvmj.bu.edu.eg)

(BVMJ-29(2): 119-128, 2015)

\section{INTRODUCTION}

$E$ scherichia (E.) coli typically colonize the gastrointestinal tract of warm-blooded animals within a few hours after birth. However, a large number of highly adapted E. coli pathogens have acquired specific virulence attributes (kaper et al., 2004). Some pathotypes of E. coli are capable of causing intestinal diseases, while others referred to as extra intestinal pathogenic E. coli (ExPEC), are responsible for extra intestinal infections. Avian pathogenic E. coli (APEC), fall under the category of ExPEC (Mellata, 2013) that induces different syndromes in poultry including, systemic and localized infections such as respiratory colibacillosis, acute colisepticemia, salpingitis, yolk sac infection, and swollen-head syndrome (Dho-Moulin and Fairbrother, 1999). Colibacillosis is a widespread disease, which is responsible for severe economic losses for the world's poultry industries. The most common form of colibacillosis is characterized by an initial respiratory disease, which is usually followed by a systemic infection with characteristic fibrinous lesions (airsacculitis, perihepatitis and pericarditis) and fatal septicemia. The infection is generally initiated or enhanced by predisposing agents, such as mycoplasmal, viral infections and environmental factors (Dho-Moulin and Fairbrother, 1999); (Barnes et al., 2008). E. coli can survive in dry, dusty conditions for 
long periods and it has been shown that wetting the litter can reduce the incidence of colisepticaemia (Black, 1990), probably due to a reduction in the numbers of $E$. coli. Feed ingredients and water are often contaminated with pathogenic coliform and are common source of introducing new serotypes into a flock (Martins, et al., 2007). The species of E.coli are serologically divided in serogroups and serotypes on basis of their antigenic composition (somatic or $\mathrm{O}$ antigens for serogroups and flagella or $\mathrm{H}$ antigens for serotypes ).Many strains express a third class of antigens(capsular or $\mathrm{K}$ antigens) (Compos et al., 2004).Antimicrobial therapy is an important tool in reducing both the incidence and mortality associated with avian colibacillosis. The long-term use of antimicrobials for therapy and growth promotion in poultry resulted in drug resistance in Gram-negative pathogens (Singer and Hofacre, 2006).Serogrouping and detection of some virulence associated genes in randomly selected isolates using a previously designed multiplex PCR (Johnson et al., 2008). This study aimed to determine the prevalence, serotypes and antimicrobials susceptibility profile of avian pathogenic $E$. coli (APEC) strains in broilers farms in winter and summer seasons in Menofyeia Government, Egypt and detection of some virulence genes of the isolated strains by using PCR.

\section{MATERIAL AND METHODS}

\subsection{Chicken samples:}

A total of 205 chicken samples from apparently healthy broiler chickens (35 and 30), diseased broiler chickens(35 and 30) and freshly dead ones(35 and 40) were collected in winter(from December to February )and summer (from June to August) seasons, respectively from Menofyiea government.The samples were collected from liver, Heart blood, kidneys and spleen .

\subsection{Detection of E.coli by conventional method: According to Quinn et al., (2002).}

\subsubsection{Selective enrichment of E.coli:}

Each sample was inoculated separately into buffer peptone water and incubated at $37^{\circ} \mathrm{C}$ for $18-24 \mathrm{hrs}$ under aerobic condition.

\subsubsection{Colonization of E. coli:}

On selective differential solid media, a loopful from the broth of each sample was streaked onto MacConkey's agar and Eosin Methylene blue agar. The inoculated plates were incubated at $37^{\circ} \mathrm{C}$ for 24 hours. Suspected E. coli colonies were purified and kept for further identification.

\subsubsection{Identification of suspected E. coli colonies:}

It was performed according to Quinn et al., (2002): On MacConkey's agar and Eosin Methylene blue agar (EMB).

\subsubsection{Microscopic examination:}

Gram's stain was prepared and used as described by Cruickshank et al., (1975) for morphological characterization.

\subsubsection{Biochemical Identification:}

According to Quinn et al., (2002) including Indole reaction, Methyl red test, Voges Proskauer test, Citrate utilization test, Catales test, Sugar fermentation test, Oxidase test, Triple sugar iron and Christener's urea agar test.

\subsubsection{Serological identification of E. coli:}

According to Edwards and Ewing, (1972) Isolated strains were serotyped in animal health research institute, Dokki, Giza using: Polyvalent and monovalent diagnostic E. coli antisera.

\subsection{Antibacterial sensitivity test:}

The disk diffusion technique was applied according to Cruickshank et al., (1975) Eight antibiotic discs were used (amoxacillin/claviulinic acid, chloramphenicol, erythromycin, doxycyclin, streptomycin, gentamycin, neomycin and 
norfloxacin). The interpretation of inhibition zones of tested culture was according to CLSI, (2012).

\subsection{Virulence genes of E. coli detection by PCR}

Multiplex PCR was applied by using four sets of primers for detection of four virulence genes that may play a role in virulence of APEC. These genes were eaeA (intimin or E. coli attaching and effacing gene); ompA (outer membrane protein); stx1 (shiga-toxin1 gene) and stx2 (shigatoxin2 gene). It was applied on isolated $E$. Coli Following QIA amp DNA mini kit instructions (Catalogue no.51304); Emerald Amp GTPCR mastermix (Takara) Code No. RR310A kit and agarose gel electrophoreses by Sambrook et al., (1989).

\section{RESULTS}

\subsection{Incidence of E. coli infection in broiler chicken samples in winter and summer seasons:}

Morphologically E. coli isolates were gramve rods appeared as pink colonies when cultured on MacConkey media and green metallic colonies on EMB medium. Biochemically, all E.coli suspected isolates were lactose fermenting colonies, positive indole, methyl red, and Catalase. Meanwhile all isolates were negative oxidase, urea hydrolysis, citrate utilization, VogesProskauer and didn't produce $\mathrm{H}_{2} \mathrm{~S}$. The prevalence of suspected E.coli isolates from dead chickens was $55 \%$, followed by diseased broiler chickens was $37.1 \%$ and from apparently healthy broiler chickens was $15.7 \%$ in winter and isolated from dead chickens $18.7 \%$, followed by diseased broiler chickens was $17.5 \%$ and from apparently healthy broiler chickens was $15.8 \%$ in summer season. This indicate that the prevalence of $E$. coli isolates is higher in winter than summer Table (1).

\subsection{Recovery rate of E.coli from internal organs :}

The high incidence of E.coli was recovered from liver $39.04 \%$ and $27 \%$,followed by fresh heart blood $36.2 \%$ and $25 \%$, spleen $35.2 \%$ and $9 \%$ and kidneys $33.3 \%$ and $9 \%$ both in winter and summer seasons ,respectively. Table (2 and 3).

\subsection{Serotyping of E. coli isolates isolated from examined broiler chicken's samples:}

The most commonly detected E. coli serogroups were $\mathrm{O}_{128}, \mathrm{O}_{78}, \mathrm{O}_{111}, \mathrm{O}_{114}, \mathrm{O}_{55}$, $\mathrm{O}_{124}, \mathrm{O}_{142}, \mathrm{O}_{1}$ and $\mathrm{O}_{2}$ (Table ,4).

\subsection{Antibiotic sensitivity test of the isolated E. coli strains:}

By using different eight antibiotic discs we found that the isolated E. coli were highly sensitive for norfloxacin $(60 \%)$, gentamycin (50\%), neomycin $(50 \%)$, streptomycin $\quad(50 \%)$ and chloamphenicol $(50 \%)$. moderately sensitive for doxcyclin (10\%) and erythromycin (40\%) and highly resistant for amoxacillin /clavulinic acid (0\%). (Table, 5)

\subsection{PCR for Detection of some virulence Genes of E.coli:}

The results of multiplex PCR showed that eae $A$ gene detected in $\mathrm{O}_{128}, \mathrm{O}_{55}, \mathrm{O}_{1}$ and $\mathrm{O}_{2}$ , OmpA gene detected in all E. coli serogroups that isolated $\mathrm{O}_{78}, \mathrm{O}_{111}, \mathrm{O}_{128}$, $\mathrm{O}_{55}, \mathrm{O}_{2}, \mathrm{O}_{1}, \mathrm{O}_{142}, \mathrm{O}_{114}$ and $\mathrm{O}_{124}$, st $x_{1}$ gene not detected in all E.coli sergroups that isolated ,but stx 2 gene detected in $\mathrm{O}_{114}$ and $\mathrm{O}_{128}$. (Table ,6) (Figure 1,2,3,4).

\section{DISCUSSION}

E.coli is considered a member of the normal microflora of the poultry intestine but certain strains such as those designated as avian pathogenic E.coli (APEC) spread into various internal organs and cause colibacillosis characterized by systematic fatal disease (Someya et al ., 2007).Typing of isolated bacteria including E.coli could be achieved by phenotypic and/or genotypic protocols. The phenotypic characteristic method used for identification of E.coli includes the morphological and 
Table (1) Incidence of E.coli infection in winter and summer seasons in chicken samples.

Winter Summer Total

\begin{tabular}{lccccccccc}
\cline { 2 - 4 } & $\begin{array}{c}\text { No. of } \\
\text { examined } \\
\text { sample }\end{array}$ & $\begin{array}{c}\text { No. of } \\
\text { +ve } \\
\text { sample }\end{array}$ & $\%$ & $\begin{array}{c}\text { No. of } \\
\text { examined } \\
\text { sample }\end{array}$ & $\begin{array}{c}\text { No. of } \\
\text { +ve } \\
\text { sample }\end{array}$ & $\begin{array}{c}\text { No. of } \\
\text { examined } \\
\text { sample }\end{array}$ & $\begin{array}{l}\text { No. of } \\
+ \text { ve } \\
\text { sample }\end{array}$ & $\%$ \\
\hline $\begin{array}{l}\text { Apparently } \\
\text { health }\end{array}$ & 35 & 13 & 37.1 & 30 & 10 & 33.3 & 65 & 23 & 35.3 \\
$\begin{array}{l}\text { Diseased } \\
\text { Freshly }\end{array}$ & 35 & 19 & 54.2 & 30 & 12 & 40 & 65 & 31 & 47.6 \\
dead & 35 & 32 & 91.4 & 40 & 19 & 47.5 & 75 & 51 & 68 \\
Total & 105 & 64 & 60.9 & 100 & 41 & 41 & 205 & 105 & 51.1 \\
\hline
\end{tabular}

$\%$ were calculated according to the numbers of examined broiler chickens.

Table (2): Incidence of $E$. coli infection in different organs in winter season:

\begin{tabular}{|c|c|c|c|c|c|c|c|c|c|c|}
\hline & \multicolumn{2}{|c|}{$\begin{array}{c}\text { Liver } \\
\mathrm{N}=105\end{array}$} & \multicolumn{2}{|c|}{$\begin{array}{l}\text { Heart blood } \\
\mathrm{N}=105\end{array}$} & \multicolumn{2}{|c|}{$\begin{array}{l}\text { Spleen } \\
\mathrm{N}=105\end{array}$} & \multicolumn{2}{|c|}{$\begin{array}{l}\text { Kidney } \\
\mathrm{N}=105\end{array}$} & \multicolumn{2}{|c|}{$\begin{array}{c}\text { Total } \\
\mathrm{N}=420\end{array}$} \\
\hline & $\begin{array}{c}\text { No of } \\
\text { +ve } \\
\text { samples }\end{array}$ & $\%$ & $\begin{array}{c}\text { No of } \\
\text { +ve } \\
\text { samples }\end{array}$ & $\%$ & $\begin{array}{c}\text { No of } \\
\text { +ve } \\
\text { samples }\end{array}$ & $\%$ & $\begin{array}{c}\text { No of } \\
\text { +ve } \\
\text { samples }\end{array}$ & $\%$ & $\begin{array}{c}\text { No of +ve } \\
\text { samples }\end{array}$ & $\%$ \\
\hline $\begin{array}{l}\text { Apparently } \\
\text { health } \\
\mathrm{N}=35\end{array}$ & 3 & 2.8 & 6 & 17.1 & 7 & 20 & 6 & 17.1 & 22 & 15.7 \\
\hline $\begin{array}{l}\text { Diseased } \\
\mathrm{N}=35\end{array}$ & 16 & 45.7 & 11 & 31.4 & 10 & 28.5 & 15 & 42.8 & 52 & 37.1 \\
\hline $\begin{array}{l}\text { Freshly dead } \\
\mathrm{N}=35\end{array}$ & 22 & 62.8 & 21 & 60 & 20 & 57.1 & 14 & 40 & 77 & 55 \\
\hline $\begin{array}{l}\text { Total } \\
\mathrm{N}=105\end{array}$ & 41 & 39.04 & 38 & 36.1 & 37 & 35.2 & 35 & 33.3 & 151 & $\begin{array}{c}35 . \\
9\end{array}$ \\
\hline
\end{tabular}

$\%$ were calculated according to number of examined broiler chicken samples.

Table (3): Incidence of E. coli infection in different organs in summer season:

\begin{tabular}{|c|c|c|c|c|c|c|c|c|c|c|}
\hline & \multicolumn{2}{|c|}{ Liver } & \multicolumn{2}{|c|}{ Heart blood } & \multicolumn{2}{|c|}{ Spleen } & \multicolumn{2}{|c|}{ Kidney } & \multicolumn{2}{|c|}{$\begin{array}{c}\text { Total } \\
\mathrm{N}=400\end{array}$} \\
\hline & $\begin{array}{c}\text { No of } \\
+ \text { ve } \\
\text { samples }\end{array}$ & $\%$ & $\begin{array}{c}\text { No of } \\
\text { +ve } \\
\text { samples }\end{array}$ & $\%$ & $\begin{array}{c}\text { No of } \\
\text { +ve } \\
\text { samples }\end{array}$ & $\%$ & $\begin{array}{c}\text { No of } \\
\text { +ve } \\
\text { samples }\end{array}$ & $\%$ & $\begin{array}{c}\text { No of } \\
+ \text { ve } \\
\text { samples }\end{array}$ & $\%$ \\
\hline $\begin{array}{l}\text { Apparently } \\
\text { health }\end{array}$ & 7 & 20 & 6 & 23.3 & 3 & 10 & 3 & 10 & 19 & 15.8 \\
\hline $\begin{array}{c}\mathrm{N}=30 \\
\text { Diseased }\end{array}$ & 9 & 26.6 & 8 & 30 & 3 & 10 & 1 & 3.3 & 21 & 17.5 \\
\hline $\begin{array}{c}\mathrm{N}=30 \\
\text { Freshly dead }\end{array}$ & 11 & 27.5 & 11 & 27.5 & 3 & 7.5 & 5 & 12.5 & 30 & 18.7 \\
\hline $\begin{array}{c}\mathrm{N}=40 \\
\text { Total } \mathrm{N}=100\end{array}$ & 27 & 27 & 25 & 25 & 9 & 9 & 9 & 9 & 70 & 17.5 \\
\hline
\end{tabular}


Table (4) Serotyping of $E$. coli isolates recovered from chicken sample:

\begin{tabular}{lcc}
\hline Isolated serogroups & No. of isolates & $\%$ \\
\hline $\mathrm{O}_{128}: \mathrm{H}_{2}$ & 5 & 23.8 \\
$\mathrm{O}_{78}$ & 4 & 19.04 \\
$\mathrm{O}_{111}: \mathrm{H}_{4}$ & 3 & 14.28 \\
$\mathrm{O}_{124}$ & 2 & 9.5 \\
$\mathrm{O}_{55}: \mathrm{H}_{7}$ & 2 & 9.5 \\
$\mathrm{O}_{142}$ & 1 & 4.7 \\
$\mathrm{O}_{2}: \mathrm{H}_{6}$ & 2 & 9.5 \\
$\mathrm{O}_{114}$ & 1 & 4.7 \\
$\mathrm{O}_{1}: \mathrm{H}_{7}$ & 1 & 4.7
\end{tabular}

$\%$ were calculated according to number of isolated serogroups.

Table (5) Result of antibiotics sensitivity of E. coli by disc diffusion method

\begin{tabular}{lcccccccc}
\hline Isolates & $\mathrm{AMC}$ & $\mathrm{S}$ & $\mathrm{E}$ & $\mathrm{C}$ & $\mathrm{DO}$ & $\mathrm{NOR}$ & $\mathrm{CN}$ & $\mathrm{N}$ \\
\hline Sensitive & 0 & 5 & 4 & 5 & 1 & 6 & 5 & 5 \\
Intermittent & 0 & 0 & 3 & 2 & 2 & 1 & 2 & 2 \\
Resistance & 10 & 5 & 3 & 3 & 7 & 3 & 3 & 3 \\
$\% *$ & 0 & 50 & 40 & 50 & 10 & 60 & 50 & 50 \\
\hline
\end{tabular}

Sensitivity percent, CN: gentamycin, E: erythromycin, s: streptomycin, C: chloramphenicol, AMC: Amoxacillin /clavulinic acid, DO: Doxycyclin, NOR: Norfloxacin, N:Neomycin.

Table (6): The results of PCR amplifications of different used genes of E. coli serogroups

\begin{tabular}{lcccc}
\hline \multicolumn{1}{c}{ Sample } & \multicolumn{4}{c}{ Results } \\
& eaeA & ompA & stx & Stx \\
\hline $1\left(\mathrm{O}_{78}\right)$ & - & + & - & - \\
$2\left(\mathrm{O}_{111}: \mathrm{H}_{4}\right)$ & - & + & - & - \\
$3\left(\mathrm{O}_{114}: \mathrm{H}_{2}\right)$ & - & + & - & + \\
$4\left(\mathrm{O}_{128}: \mathrm{H}_{2}\right)$ & + & + & - & + \\
$5\left(\mathrm{O}_{55}: \mathrm{H}_{7}\right)$ & + & + & - & - \\
$6\left(\mathrm{O}_{2}: \mathrm{H}_{6}\right)$ & + & + & - & - \\
$7\left(\mathrm{O}_{142}\right)$ & + & + & - & - \\
$8\left(\mathrm{O}_{124}\right)$ & - & + & - & - \\
& & & & \\
\hline
\end{tabular}

- eaeA (intimin or E. coli attaching and effacing gene), ompA (outer membrane protein). stx2(shiga-toxin2 gene), stx1(shiga-toxin1 gene). 


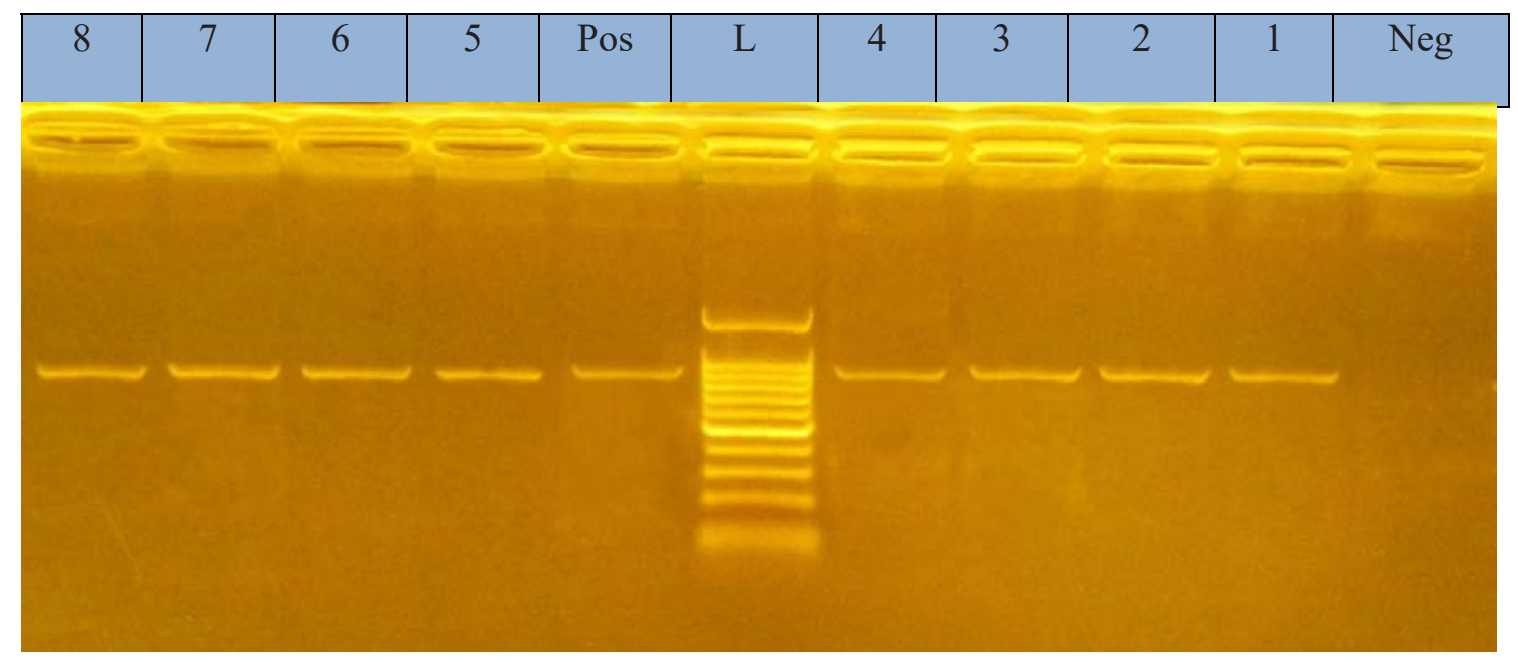

Figure (1): Results of PCR for amplification of ompA gene of E.coli serogroups . Lane L: 1001500bp DNA Ladder. Neg.: Negative control. Pos. : Positive control. Lane 1,2,3,8 : E.coli $\mathrm{O}_{78} \& \mathrm{O}_{111}: \mathrm{H}_{4} \& \mathrm{O}_{114}: \mathrm{H}_{2} \& \mathrm{O}_{124}$ (positive). Lane4,5 : E.coli $\mathrm{O}_{128}: \mathrm{H}_{2} \& \mathrm{O}_{55}: \mathrm{H}_{7}$ (Positive). Lane 6,7 : E.coli $\mathrm{O}_{2}: \mathrm{H}_{6} \& \mathrm{O}_{142}$ (Positive)



Figure (2): Results of PCR for amplification of eaeA gene of E.coli serogroups. Lane L: 100600bp DNA Ladder. Neg.: Negative control. Pos.: Positive control. Lane 1, 2, 3, 8: E. coli $\mathrm{O}_{78} \& \mathrm{O}_{111}: \mathrm{H}_{4} \& \mathrm{O}_{114}: \mathrm{H}_{2} \& \mathrm{O}_{124}$ (Negative). Lane4,5: $\mathrm{O}_{128}: \mathrm{H}_{2} \& \mathrm{O}_{55}: \mathrm{H}_{7}$ (Positive). Lane 6,7: $\mathrm{O}_{2}: \mathrm{H}_{6} \& \mathrm{O}_{142}$ (Positive) 




Figure (3): Results of PCR for amplification of $s t x_{1}$ gene of E.coli serogroups: Lane L: 1001500bp DNA Ladder. Neg. : Negative control. Pos. : Positive control. Lane 1,2,3,8 : E.coli $\mathrm{O}_{78} \& \mathrm{O}_{111}: \mathrm{H}_{4} \& \mathrm{O}_{114}: \mathrm{H}_{2} \& \mathrm{O}_{124}$ (Negative). Lane4,5 : E.coli $\mathrm{O}_{128}: \mathrm{H}_{2} \& \mathrm{O}_{55}: \mathrm{H}_{7}$ (Negative). Lane 6,7 : E.coli $\mathrm{O}_{2}: \mathrm{H}_{6} \& \mathrm{O}_{142}$ (Negative)

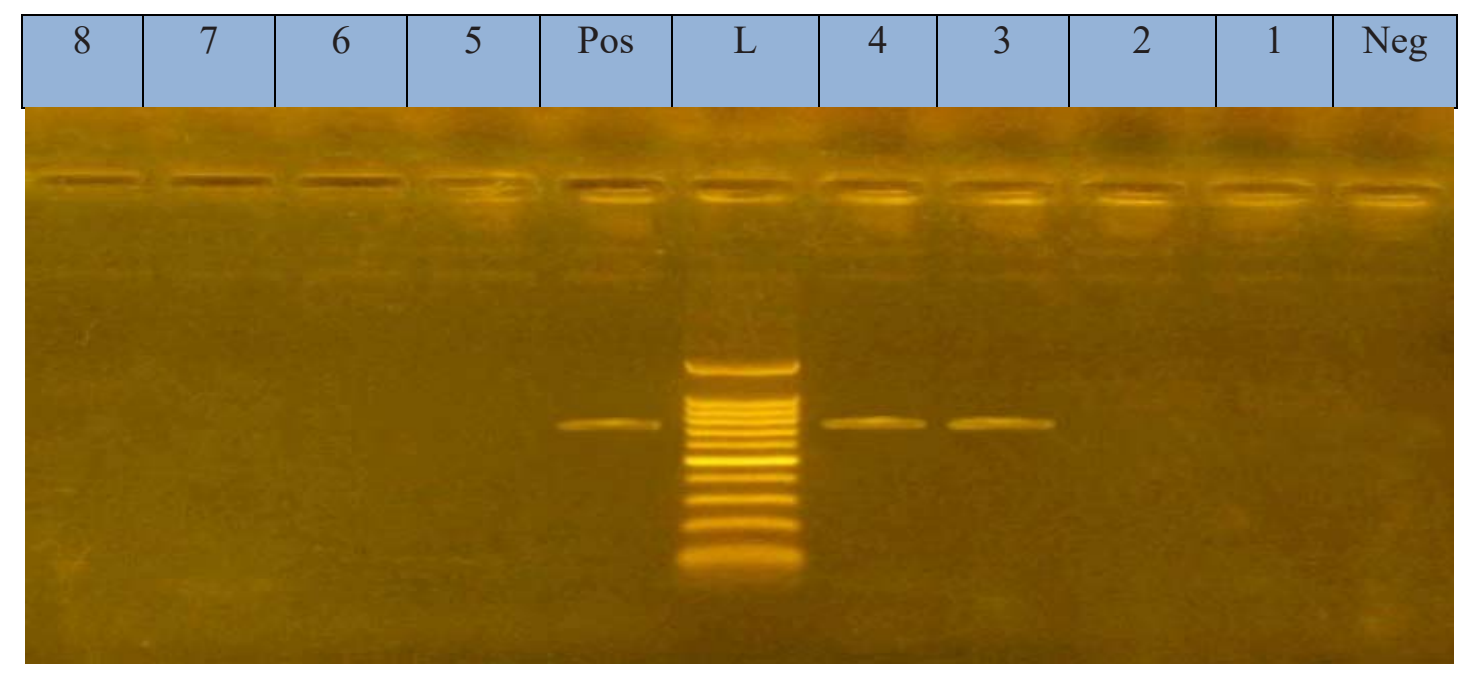

Figure (4): Results of PCR for amplification of stx 2 gene of E. coli serogroups. Lane L: 1001500bp DNA Ladder. Neg.: Negative control. Pos.: Positive control. Lane 1,2,5,8: E. coli $\mathrm{O}_{78} \& \mathrm{O}_{111}: \mathrm{H}_{4} \& \mathrm{O}_{55}: \mathrm{H}_{7} \& \mathrm{O}_{124}$ (Negative). Lane4,3: E. coli $\mathrm{O}_{128}: \mathrm{H}_{2} \& \mathrm{O}_{114}: \mathrm{H}_{2}$ (Positive). Lane 6,7: E. coli $\mathrm{O}_{2}: \mathrm{H}_{6} \& \mathrm{O}_{142}$ (Negative)

biochemical tests. Most of these techniques are not sufficiently sensitive to distinguish between different strains and they are affected by physiological factors (Fantasia et al., 1990).

Therefore, serological protocol was established to differentiate E. coli isolates. Regarding the morphological characters used for identification of $E$. coli, depend on that $E$. coli isolates are Gram-negative rods with pink colonies when cultured on MacConkey agar media, green metallic colonies on EMB medium. Nearly similar results were noted by Kumar et al., (1996) and Hogan and larry (2003). Bacteriological study was conducted on 820 randomly collected organ samples from apparently healthy broiler chickens, diseased broiler chickens and freshly dead ones including liver, fresh heart blood, kidneys and spleen isolated from four broiler 
farms located in Menofyiea government in winter and summer seasons revealed that E.coli isolates was recovered from 221 samples with overall prevalence $27.3 \%$, This study revealed that the E.coli isolates were isolated from $26.9 \%$ (221 out of 820 ) broiler chickens samples originated from different sources including; Fresh heart blood 30.7\% (63out of 205) Liver 33.1\% (68 out of 205), Kidneys 21.5\% (44 out of 205) and Spleen $22.4 \%$ (46 out of 205). These results are agreed to some extend with that obtained by Abd El Tawab, (2014) who isolated E.coli at a percentage of $38 \%$. From the above mentioned results, it is obvious that E.coli isolates were recovered from poultry farms with higher prevalence from liver samples followed by Fresh heart blood, spleen and kidneys. Nearly similar result obtained by El Sayed et al., (2015). The incidence of E.coli among examined chickens in winter was $60.9 \%$ and this percentage was higher than that in summer $41 \%$.This variation may be attributed to defects in the environmental and hygienic condition in poultry farms in winter as bad ventilation, overcrowding and high amount of ammonia in air also may be due to high incidence of E.coli in water, feed, litter and air in winter than in summer. These results agreed with those obtained by Nehal, (2009), Mahajan et al., (1994) and Ayoub ,(2007) .

It was observed that several serotypes were recovered from clinical cases of broiler chickens with different $E$. coli infection as $\mathrm{O}_{128}, \mathrm{O}_{78}, \mathrm{O}_{111}, \mathrm{O}_{124}, \mathrm{O}_{55}, \mathrm{O}_{114}, \mathrm{O}_{142}, \mathrm{O}_{2}$ and $\mathrm{O}_{1}$ (Table,4). Similarly E. coli serotypes had been previously isolated from chicken and newly hatched chicks in Egypt as reported by Abd El-Haleem, (2000) were $\mathrm{O}_{78}$ and $\mathrm{O}_{111}$, Taha et al., (2002) was $\mathrm{O}_{2}$, El-Sayed et al., (2015) were $\mathrm{O}_{111}, \mathrm{O}_{55}, \mathrm{O}_{142}$ and $\mathrm{O}_{128}$ and Reem ,(2015) were $\mathrm{O}_{142}, \mathrm{O}_{1}, \mathrm{O}_{55}, \mathrm{O}_{128} \mathrm{O}_{114}$ and $\mathrm{O}_{124}$, respectively. The results of antibiotic sensitivity tests (Table ,5) revealed that gentamycin, doxycyclin, norfloxacin and chloramphenicol were the most proper antibiotics with the highest in vitro efficiency against the isolated E.coli. These results go in parallel with those obtained by Nehal,(2009),
Sharada et al., (2010), Tapan et al., (2012) and Abd El Tawab ,(2014). Results of antimicrobials sensitivity of serotyped E.coli recovered from broilers showed that the majority of E.coli isolates were sensitive to gentamycin $(60 \%)$, norfloxacin $(60 \%)$, streptomycin $(50 \%)$, neomycin $(50 \%)$ and chloramphenicol $(50 \%)$. The results were nearly similar to that obtained by Sharada et al., (2010). The results of antibiogram in this study are in variance with the findings of other workers, indicating that antibiotic pattern varries with different isolates, time and development of multiple drug resistance among different E.coli isolates related to transmissible $\mathrm{R}$ factor/plasmid. The transmission of resistance plasmid of E.coli from poultry to human have also been reported Tapan et al., (2012). The results revealed that all E.coli isolates recovered from various chicken broiler samples were negative for $s t x_{1}$ in E.coli isolates (Table, 6) and (Figure,3). Nearly similar findings were recorded by Ahmed (2011), Mona et al., (2013) and Homaira. et al., (2015). The results of PCR amplification of Stx 2 gene in isolated E.coli strains showed that out of 8 E.coli isolates, one $(\mathrm{O} 128)$ was positive for the Stx 2 gene yielded a consistent fragment of $779 \mathrm{bp}$. (Table,6) and (Figure, 4). These results substantiate what has been reported by Abd El Tawab, (2014). Concerning the examination of $E$. coli isolates for the detection of intimin (eaeA) gene demonstrated that four isolates $\left(\mathrm{O}_{128}, \mathrm{O}_{55}, \mathrm{O}_{1}\right.$ and $\left.\mathrm{O}_{2}\right)$ out of eight isolates, yielded the expected size of 248 bp PCR amplification products for the intimin gene (Table,6) and (figure,2). These findings were nearly agreed with those obtained by Ahmed et al., (2007) and Ahmed Al-Ajmi (2011).

Finally, PCR amplification of ompA gene in isolated E. coli strains showed that the ompA gene was amplified in all $E$. coli serogroups that were isolated giving a PCR product of 919bp.(Table,6) and (Figure ,1). Similar findings were recorded by Catana et al., (2008), Johson et al., (2008), and Zhao et al., (2009) who reported that ompA gene was found in all APEC isolates. It could be concluded that $E$. coli could have isolated 
from examined samples in different farms under investigation in either winter or summer seasons. Also the isolation rate was higher in winter than in summer season and detection of some virulence genes from isolated serogroups by application of PCR.

\section{REFERENCE}

Abd El-Haleem, Y.F. 2000. Some epidemiological studies on Escherichia coli in poultry farms. M. V. Sc. Thesis, Fac. Vet. Med., Zagazig Univ.

Abd El Tawab, A.shraf, A., Ahmed, A.A. Maarouf, Samir, A. Abd El Al, Fatma, I. El Hofy and Emad, E.A. El Mougy. 2014. Detection of Some Virulence Genes of Avian Pathogenic E. Coli by Polymerase Chain Reaction. Benha Veterinary Medical Journal, 26(2):159-176.

Ahmed, W.; Tucker, J.; Bettelheim, K.A.; NBeller, R. and Katouli, M. 2007. Detection of virulence genes in Escherichia coli of an existing metabolic fingerprint database to predict the sources of pathogenic $E$. coli in surface waters. water research, 41: 3785-3791

Al-Ajmi, A.D.A.M. 2011.Escherichia coli isolated from broiler farms with special references to virulence genes of isolated strains". M.V.Sc. Thesis, Fac. Vet. Med., Zag.Univ.

Ayoub, M. A. M. 2007. Studies on epidemiology of Escherichia coli in some poultry farms. M.V.S. thesis. Faculty of vet. Med., Alexandria University.

Barnes, H.J., Nolan, L.K. and Vaillancourt, J.F. 2008. Colibacilliosis. In Diseases of Poultry (Saif, Y.M. and Fadly, A.M., eds.) Blackwell Publishing, Ames, IA, 691-732.

Black, R. C. 1990. Epidemiology of traveller's diarrhea and relative importance of various pathogens. Reviews of Infectious Disease 12:573-579.

Catana, N.L.; Virgitia, Popa.; Ionica, fodor and Maroiu, G. 2008.Molecular Screening regarding the presence of the iss genes FIM and ompA at the E. coli isolated from broiler chickens. Buletin USAMV Veterinary Medicine, 65(2): 1843-1863.

Clinical and Laboratory Standards Institute CLSI. 2012.Performance Standards for
Antimicrobial Susceptibility Testing; Twenty-Second Informational Supplement M100-S22.

Compos, L. C., Franzolin, M.R., Trabuls, L.R. 2004.Diarrheagenic E.coli Categories among the traditional enteropathogenic E.coli O-serogroups. Mem. Inst. Oswald Cruz; 99(6).545-552.

Cruickshank, H., Duguid, J.P., Marmon, B.P., Swain, R.H.A. 1975. Medical Microbiology. The practice of Medical Microbiology, 12th Ed. Churchill Livingstone, Edinburgh. London and New York.

Dho-Moulin, M. and Fairbrother, J.M. 1999. Avian pathogenic Escherichia coli (APEC). Vet. Res., 30:299-316.

Edwards, R., Ewing, H. 1972. Identification of Enterobacteriacae. Minneapolis, Burgess Publishing Co., PP. 709.

El- sayed, M.E., Shabana, I.I., Esawy, A.M., Rashed, A.M. 2015. Detection of Virulence-Associated Genes of Avian Pathogenic Escherichia Coli (APEC) Isolated from Broilers. J. Genetics. 1(1): 004.

Fantasia, M., Ricci, N., Manupella, A., Martinil, A., Filetici, E. et al., 1990. Phage type and DNA plasmid of Salmonella typhimurium isolates in the area of Isernia, Italy. Epidemiol. Infect., 105(2): 317-323. 13.

Hogan, J., Larry S.K., 2003. Coliform mastitis. Vet. Res., 34(5): 507- 519.

Homaira Anzum Himi, Md Shafiullah Parvej, M Bahanur Rahman, K, M Nasiruddin, Wahedul Karim and Md Mostakin Ahamed .2015. PCR Based Detection of Shiga Toxin Producing E. coli in Commercial Poultry and Related Environments “. Turkish Journal of Agriculture -Food Science and Technology,3(6):361-364.

Johnson, T.J., Wannemuehler, Y., Doetkott, C., Johnson, S.J., Rosenberger, S.C. and Nolan, L.K. 2008. Identification of minimal predictors of avian pathogenic Escherichia coli virulence for use as a rapid diagnostic tool. J. Clin. Microbiol., 46: 3987-3996.

Kaper, J.B., Nataro, J.P. and Mobley, H.L. 2004.Pathogenic Escherichia coli. Nat. Rev. Microbiol., 2: 123-140.

Kumar, KU., Sudhakar, R., Rao, P.P., A note on Escherichia coli infection in 
Prevalence of E. coli in broiler chickens by application of PCR with its antibiogram pattern.

poultry.2003. Poultry Adviser. 1996, 21: 49-51 14. Hogan J, Larry SK, Coliform mastitis. Vet. Res., 34(5): 507- 519.

Mahajan, N.R., Jindal, Kulshreshtha, R.C. 1994. Major broiler disease in some parts of Haryana. Indian J. Anim. Sci., 64(11):1118-1122.

Martins, D.P., Oliveira, M., Biea, A., Vaz-Pires, P., Bernardo, F. 2007. Antimicrobial resistance in Enterococcus spp. And Escherichia coli isolated from poultry feed and feed ingredients. Vet. Microbiol. 120: 122-131.

Mellata, M. 2013. Human and Avian Extra Intestinal Pathogenic Escherichia coli: Infections, Zoonotic Risks, and Antibiotic Resistance Trends. Foodborne Pathog. Dis., 10 (11): 916-932.

Mona, A. Ahmed, Fatma, M. Youssef and Abdel Rahman, A.G. 2013. Differentiation between E. coli strains causing diarrhea in broiler chicken by using multiplex PCR "Proc. 6th Inter Conf. Vet. Res. Div., NRC, Cairo, Egypt, pp. $33-47$

Nehal, A.A.N. 2009. Diversity and Prevalence of Escherichia Coli in Chickens, Environment and Related Persons. M.V.Sc. Thesis, Fac. Vet. Med., Alexandria Univ.

Quinn, P.J., Markey, B.K., Carter, M.E., Donnelly, W.J.C., Leonard, F.C. 2002. Veterinary microbiology and microbial diseases.1st Iowa State University Press Blackwell Science.

Reem, M.Said. 2015.Molecular detection of antibiotics resistant genes among $E$. coli isolated from diseased chickens. Ph.D. Thesis, Fac. Vet. Med., Benha. Univ.

Sambrook, J.; Fritscgh, E.F.; and Mentiates. 1989. Molecular coloning. A laboratory manual. Vol., Cold spring Harbor Laboratotry press, New York.

Sharada, I.R.S., Ruban, W., Thiyageeswaran, I. M. 2010. Isolation, Characterization and Antibiotic Resistance Pattern of Escherichia coli Isolated from Poultry. American-Eurasian Journal of Scientific Research 5(1): 18-22.

Singer, R.S. and Hofacre, C.L. 2006.Potential impacts of antibiotic use in poultry production. Avian Dis., 50: 161-172.

Someya, A., Otsuki, K., Murase, T.2007. Characterization of Escherichia coli strains obtained from layer chickens affected with colibacillosis in a comercial egg-producing farm. J. Vet. Med. Sci., 69(10): 1009-1014. 12.

Taha, M., Ibrahim, R.S., Asmaa, A.H. 2002. Studying the pathogenicity and RAPDPCR analysis of different Escherichia coli serotypes isolated from broilers and layer chickens. Assiut, Vet. Med. J., 46(92): 224-236.

Tapan, K.S., Lakshman, S., Laxmi, N., Sarangi, S., Kumar, P., Hemant, K.P. 2012. Prevalence, Isolation, Characterization and Antibiogram Study of Pathogenic Escherichia coli from Different Poultry Farms of Odisha. Journal of Advanced Veterinary Research 2:169-17.

Zhao, L., GAO, S., HUNAN, H., Xu, x., Zhu, x., Yang, w., Gao, Q., Liu, x. 2009.Comparison of virulence factors and expression of specific genes between uropathogenic Escherichia coli and avian pathogenic E. coli in a murine urinary tract infection model and chicken challenge model". Microbiology-Sgm, 155: 1634-1644. 